\title{
Nigerian Education and the Inculcation of Values: A Philosophical Appraisal
}

Dr. Greg Ekeh ${ }^{*}$

Department of Educational Foundations Nnamdi Azikiwe University, Awka Anambra State, Nigeria

\begin{tabular}{ll}
\hline DOI: $10.36348 /$ jaep.2019.v03i11.005 & | Received: $01.11 .2019 \mid$ Accepted: $08.11 .2019 \mid$ Published: 24.11 .2019 \\
*Corresponding author: Dr. Greg Ekeh &
\end{tabular}

\section{Abstract}

Inculcation and practice of values are indispensable for social coherence and development in any human society. As guiding principles for accepted behavior in the society, values are highly informed and influenced by cultural and social contexts. Virtually every nation counts on education as a veritable instrument for the inculcation of values. Every nation has its own set of values which it considers to be catalytic to its development if well inculcated through education. Nigeria, as a nation, has such values. However, it is doubtful, based on the apparent depravity and perversion prevalent in the country, if the Nigerian education is effectively carrying out this task of inculcation of values in the students. This paper, therefore, deemed it necessary to carry out a philosophical appraisal in this regard, using the method of conceptual and critical analysis. The outcome of the appraisal showed that although the outlined values in the National Policy on Education are noble, the Nigerian education system has not been effective in inculcating those values, due to a number of reasons, such as the absence of value clarification, lack of strong emphasis on the practice of values, neglect of some core Nigerian traditional values and teachers' ill preparedness for the responsibility of inculcating values. Based on this, the paper recommended, among others, that efforts should be made at value clarification, modification of the policy statement so as to strongly emphasize practical aspects as well as our core traditional values, and that adequate attention be given to in-depth knowledge of values in the training and retraining of teachers of all cadres.

Keywords: Inculcation values depth knowledge cadres.

Copyright @ 2019: This is an open-access article distributed under the terms of the Creative Commons Attribution license which permits unrestricted use, distribution, and reproduction in any medium for non-commercial use (NonCommercial, or CC-BY-NC) provided the original author and sources are credited.

\section{INTRODUCTION}

The question of values has been a very important one, not only in education, but also in the domain of philosophy and in the society at large. Every society has its own set of values, both in the primitive and modern settings. Such values are transmitted from generation to generation. Nigeria, as a society, has identified a number of values which are to be pursued through education at all levels. This is in keeping with the global stance that education remains the most effective instrument for social transformation and development. According to Onuoha [1], Education is "a process by which the individual is enabled to develop his capabilities through the acquisition of knowledge, skills, values and attitudes both for his own benefit and for the benefit of the society".

This paper is an attempt at a philosophical appraisal of this all-important function in the context of Nigerian education system. Areas of attention in this discussion are: Concept of education, education in Nigerian context, and the concept of value. Also to be considered are the identified values to be inculcated and transmitted through Nigerian education, and challenges to the inculcation of those values. This will be followed by philosophical appraisal, recommendations, and then the conclusion.

\section{Concept of Education}

Education can be viewed from many perspectives, such as traditional, formal or informal. The perspective adopted here is that of formal or school education. In this regard, Plato's concept of education is very informative. Plato [2] holds that education is the process that urges a person to eagerly pursue the ideal perfection of citizenship, and teaches him how rightly to rule and how to obey, and that those who are rightly educated generally become good people. Plato's view depicts education as a character molder. Commenting on this, Ekeh [3] states that "those who go through the process of education are expected to be good citizens, upright, just, incorruptible and patriotic. Tricks, deceptions and manipulation of people and things to one's own advantage and to the disadvantage of others, 
should be far removed from the characteristics of the educated". For Fafunwa [4], "Education is the aggregate of all the processes by which a child or young adult develops the abilities, attitudes, and other forms of behaviour which are of positive values to the society in which he lives". This definition by Fafunwa links education with the society. It sees education as a social institution for the transmission of worthwhile values. This implies that no education system should overlook norms and values of the society, but instead endeavor to inculcate them in the learners.

Education can also be viewed in terms of human development. In this regard, Otite and Ogionwo [5] conceive education as the process of acquiring knowledge and skills required to adapt to and exploit the social and physical environment in the process of development. Development here refers to human development in all aspects: morally, intellectually, spiritually and emotionally. In this sense, education becomes a veritable instrument of individual and social empowerment and emancipation. For Dewey [6], education is a social institution through which social reform can and should take place. He is of the view that education brings about balanced experience in the society. In this regard he states that:

Discipline, culture, social efficiency, personal refinement, improvement of character are but phases of the growth of capacity nobly to share in such a balanced experience. And education is not a mere means to such a life. Education is such a life. To maintain capacity for such education is the sense of morals (p. 169).

It can be noticed that Dewey believes so much in education as a social process through which the learners are brought to share in the inherited resources of the society and to use their own powers and acquired skills for the ends of the society. Dewey is not only concerned about the present but also the future of the society. He is therefore of the view that all that the society has achieved for itself is put at the disposal of its future members through the agency of the school [6].

In consideration of the concepts of education as presented above, one can say that education is a process of teaching and learning, the aim of which is to bring about a holistic formation of the individuals through the inculcation of values, skills and attitudes to be put into practice for the purpose of individual and social transformation and development. As a process, education is a gradual but steady means of values inculcation, transmission, orientation and reorientation. Values in this context include the people's culture, philosophy, literature, art, music, religion, politics, science, technology, ideas and attitudes. Education is thus an ongoing effort in the preservation, modification and transmission of the society's way of life through its process of imparting knowledge. It is therefore considered worthwhile and desirable in every society. Every nation, including Nigeria, has its own system of education through which it hopes to achieve its national goals, based on its philosophy.

\section{Education in Nigerian Context}

The import of Nigerian education is articulated in the document National Policy on Education. The formulation of the policy on education as outlined in the policy document is informed by the identified overall philosophy of Nigeria as a nation. Hence the Federal Republic of Nigeria, F. R. N. [7] states that the overall philosophy of Nigeria is to:

(a) "Live in unity and harmony as one indivisible, indissoluble democratic and sovereign nation founded on the principles of freedom, equality and justice;

(b) Promote inter-African solidarity and world peace through understanding". Begin with a paragraph: The above philosophy is an indication that peace and unity are uppermost in the mind of

Nigeria as a nation. It is hoped that in the atmosphere of peace and unity, the main national goals of Nigeria could be achieved. The main five national goals are the building of:

(a) "a free and democratic society;

(b) a just and egalitarian society;

(c) a great and dynamic economy;

(d) a land full of bright opportunities for all citizens"

(F. R. N., 2014:4).

In Nigerian philosophy of education, it is believed that education is an instrument for national development, and that there is need for education to be functional for the purpose of a progressive, united Nigeria [7]. For this to be, some values ought to be inculcated through education.

\section{Concept of Values}

Value is a familiar concept both in philosophy and education. No individual or society can properly function without values. Values are beliefs strongly held regarding desirable ends, principles or conditions accepted as guides to the choice, evaluation and approval of behaviours in the context of the individual or the society. The idea being conveyed here is that value is a personal or social standard for the approval or disapproval of events as they relate to the individual or society in question. In a similar viewpoint, Okoro [8] states that "value may be considered as the 'good' desired or cherished by the individual or group".

Values are usually attached to desire. This means that there must be elements of goodness in whatever is desired or cherished for it to qualify as a value. A thing of value is thus desired for its own sake, as an end in itself. In this respect, Nwabuisi [9] opines that "values can be described as ends, not means. Their 
Greg Ekeh; J Adv Educ Philos, Nov 2019; 3(11): 414-419

desirability is either unconsciously taken for granted or seen as a direct derivation from one's experience or from external authority". For Inlow [10], value is the determinant factor in man that influences his choices, decision makings and behavioural patterns in life.

In the light of the above considerations, values can be understood as those ideals inherent in things or imbibed by individuals or groups, what constitutes the desirability the individuals or groups have for those things, or determine the standards of what they think, say and do, approve or disapprove, with regard to their individual or group lives and relationships with others.

\section{Values to be inculcated through Education in Nigeria}

As outlined in the National Policy on Education, the following are the values to be inculcated through education:

(a) "Respect for the worth and dignity of the individual;

(b) Faith in man's ability to make rational decisions;

(c) Moral and spiritual principle in inter-personal and human relations;

(d) Shared responsibility for the common good of society;

(e) Promotion of the physical, emotional and psychological development of all children; and

(f) Acquisition of competencies necessary for selfreliance [7]".

According to the policy statement, for education to achieve these goals and values, all other agencies will collaborate with education, and education shall continue to be highly rated in the national development plans, since "education is the most important instrument of change" [7]. It is believed that the inculcation and acquisition of these values will be a boost to equipping the citizens for life challenges and responsibilities, and also for the task of nation-building. It is the responsibility of the education system to pursue the inculcation of these values at all levels. It is therefore pertinent to ask: Is Nigerian education system living up to this responsibility for the overall wellbeing of the Nigerian nation and its citizens?

\section{Philosophical Appraisal}

From philosophical perspective, value is generally understood as "the worth of something [11]", with different forms as intrinsic, instrumental, inherent and contributory. Regarding the values to be inculcated through education as outlined in the National Policy on Education, the following questions readily come to mind: Under which forms were these values categorized to justify their selection? Are there strategies for value clarification for the purpose of guiding choices and behaviours? How effective has the education system been in its responsibility of value inculcation, and what are the evidences on ground to the proof thereof, considering the situation of things in the country since the publication of the policy document? Are these values sufficiently indigenous and capable of enhancing our life as a nation and triggering our national development?

\section{Forms of Values}

Four main forms of values have been identified by philosophers. These are intrinsic, instrumental, inherent and contributory. According to Audi [11], an intrinsic value can be explained "in terms of the sorts of emotions and desires appropriate to a thing in and for itself", that is, for its own sake and not for any other reason. In other words, an intrinsic value is perceived as an end in itself. Looking at the identified values to be inculcated through education as outlined in the National Policy on Education, one would ask: Are these values worthy of desire for their own sake? Is it appropriate to choose these values in and for themselves? The answers to these questions can be in the affirmative. We don't need to look for an external end before showing respect for the worth and dignity of the individual, for instance, or having faith in man's ability to make rational decisions. However, the acquisition of necessary competencies seems to be a means rather than an end, for its purpose is to attain self-reliance.

A value is instrumental if it serves as a means of achieving some other value, considered to be intrinsic. For instance, if preservation of life is an intrinsic value and eating balanced diet is a means to it, then eating balanced diet is an instrumental value. If the experience of a thing is intrinsically valuable, then that thing has an inherent value. For example, if the experience of a peaceful atmosphere is intrinsically valuable, then a peaceful atmosphere has an inherent value. This implies that the type of experience gained resides in the peaceful atmosphere. If a value contributes to the overall good of a whole, of which it is a part, then the value is said to be contributory. For instance, if success in examination is a whole that consists of the fact that the teacher works hard and students also work hard, then the fact that students work hard is a contributory value to the value of success in examination.

From the knowledge of the forms of values, it can be argued that the values to be inculcated through education as outlined in the policy document are a combination of all the forms. They have qualities of being intrinsic, instrumental, inherent and contributory. This is because they can be pursued for their own sake, for the purpose of achieving other values, for enjoying valuable experience, or as part of a valued whole. In this respect, one can say that the choice of the values are justifiable. Referring to the values, Nwabuisi [9] states that "the National Policy on Education has enunciated noble values on which Nigerian educative principles and practices should be built". 
In spite of the above credit, some scholars have raised concerns regarding the need for value system and value clarification within the contexts and discernible needs of Nigerian society and its citizens. For instance, Osaat [12] queries whether we, as a nation, have a realistic and comprehensive value system that is inclusive and amenable to all the diverse segments of the country. This is in line with the observation by Ifeagwazi and Uzondu [13] that "Individualistic orientation seems to be the dominant orientation in contemporary Nigerian society as most Nigerians have lost the sense of community, sharing of resources, mutual cooperation and collaboration". According to Collins [14], value system is a set of values and beliefs according to which people, a group or organization regulate their behaviour. Value clarification is an educational intervention concerned with reflexive personal, socio-cultural and intellectual processes through which a person strives to identify the value priorities to guide his or her choices, interests, actions and reactions within the diversity of interpersonal and social contexts, as explained by Kulich and Chi [15]. The same Kulich and Chi go on to maintain that value clarification enhances a better and realistic self-understanding in relation to social norms, responsibilities, expectations and opinions. In this context, value clarification presupposes an existence of an objective value system as a point of reference. Value system is a set of consistent ethical values, norms and measures established by a society for the purpose pursuing, attaining and sustaining its ethical or ideological integrity. For Agarwal [16], value system is elaborate and embraces all aspects of moral principles in human development passed on from one generation to another through indigenous education system. However, it is doubtful if Nigeria as a nation has such a system of values, based on her indigenous education. For Osaat and Omordu [17], the value system in Nigeria is subjective and relative. It creates a situation in which everyone acts according to his or her own personal conviction, often without reference to any operating natural and universal principles.

Perhaps it is assumed that teachers are to take the responsibility of this clarification through their roles of teaching and guiding the students. In this regard, Fan and Bawa [18] state that value clarification is a process through which the teacher helps his student in making personal choices, through the development of personal values in the context of his personal experiences in life. The implication here is that teachers are expected to be well knowledgeable in matters of values and policy statements of the National Policy on Education, and that he should be a model to the students through his personal character. Fan and Bawa, therefore, argue that the teacher must be a mirror of what he teaches. This being the case, he would be able to analyze values, take up their clarifications, and link them with the accepted norms in the society [19].
In light of the above assumption and expectation, a question may be asked: Are the Nigerian teachers well knowledgeable, value-wise, and well aware of the tenets of the National Policy on Education? The findings of a study on teachers' awareness of the value component of the National Policy on Education by Saheed and Ado [20] reveal that secondary school teachers have no access to the National Policy on Education, and possess moderate level of awareness of the value component of the policy document. Based on the findings, they suggest that the in-service training of teachers should include acquisition of skills for identifying value components of school subjects and that teachers of all cadres be accommodated in re-training programmes. These findings and suggestions show that teachers are not well prepared and equipped for the task of inculcating values in the students. Moreover, it seems much emphasis is not given to the affective domain in the process of teaching and evaluation of students, and that there is no specific schedule for the inculcation of values, as observed by Ohwovorione [21]. According to him, moral values belong properly to the affective domain.

If teachers are not well prepared and equipped for inculcating values in the students, and students are not properly evaluated in the affective domain, it then implies that the education system is not effectively carrying out its responsibility with regard to the inculcation of values. The absence of specific schedule for the inculcation of values impels one to wonder whether it is assumed that already the values in question are incorporated in all the subjects or courses taught in the process of school education. Even if they are incorporated, which is doubtful, what are the measures to be taken to ensure the practice of these values, both within and outside the school environment? It seems the focus has been on the inculcation and acquisition, without corresponding emphasis on the practice. In this regard, the observation made by Frankena [22], about four decades ago, is still relevant here. He argues that the major problem is how to get the learners to choose the good and reject the evil. In other words, efforts are to be put forth to help the learners to behave appropriately in accordance with the acquired knowledge of values.

From the way the values to be inculcated are outlined, it appears as if the policy document perceives values as being at par with other subjects such as English, Mathematics, and so on, which can just be taught and learnt straightforwardly in the process of education. Perceiving values in this manner tilts them towards the cognitive and motor domain, without much reference to the affective domain. In this way the essence of their worthwhileness is either vaguely captured or entirely lost.

In philosophy, values fall within the domain of prescriptive philosophy, in which they are understood 
Greg Ekeh; J Adv Educ Philos, Nov 2019; 3(11): 414-419

as guiding principles for accepted behaviours in the society, ideas about what is important in life [23], and basic beliefs and attitudes in a society, accepted as worthwhile, and function as guides to daily life choices and behaviours [24]. From this perspective, it follows that cultural and social contexts have great influence in the determination of values. In this connection, Aggarwal [16] states that value system is elaborate and includes all aspects of moral principles in human development passed on from generation to generation through indigenous education. Did our indigenous education, cultural and social contexts influence the determination of the values outlined in the National Policy on Education?

Among the Nigerian traditional values are sanctity of human life, truthfulness, hard work, respect for elders, fairness, honesty, altruism, dedication, modesty, respect for self and others. Solarin [25], however, laments that these values were not given prominence in the policy statement, despite the fact that these are the values that enhance social life and catalyze development. According to Eluu [26], education, as a social instrument for the expansion of human culture, transmission of values and accumulated knowledge of a society, may be formal, informal or non-formal. Cognizant of this, it can be said that there is an over dependence on school education for the inculcation of values, even when teachers and the school system are not well equipped and empowered for it, to the neglect of the roles of informal and non-formal education. Emphasis on inculcation of values should be expanded to include good parenting, the roles of the community, religious bodies and peer influence. Moreover, our value system ought to reflect our roots and indigeneity, with strong emphasis on practical applications.

Ideally, the policy statement on values is supposed to be modified so that the quality of education at all levels of, as well as in informal and non-formal education, has to be oriented towards the inculcation and practice of those values. Leaving it only at the level of inculcation vitiates the domain of practice, both on the part of the teachers, the learners and other stakeholders, such as the parents, political leaders, and the rest of the significant others, who should be looked upon as models to the learners. In the area of respecting the worth and dignity of the individual, for instance, Nwabuisi [9] avers that "Nigerian government must demonstrate respect for the worth of the individual before delegating the teacher to teach it in the school. This demonstration in practice inculcates in the students the values in question more than what the teacher will teach".

Another twist to the inculcation, acquisition and practice of values is that there was no preparatory ground, no conducive political atmosphere, to engage the holistic attention and interest of teachers and learners in this regard. Such a preparatory ground, such a conducive political atmosphere, would begin by giving and having a sense of belonging with reference to all the segments of the Nigerian society, irrespective of ethnic, religious, economic or political backgrounds. How, for instance, can shared responsibility for the common good of all make sense to teachers and students when our leaders resist the payment of minimum wage, but appropriate scandalous sums for themselves; when they neglect the health sector and travel abroad for their own medical attentions; when they neglect the need for adequate funding of public schools and send their children to the best schools abroad; when they close their eyes to the death traps to which our roads have turned into, and hover around in private jets? Where is their own sense of common good?

In the light of the above scenario, the effort to inculcate values through education has apparently been overwhelmed. Little wonder there is widespread of all manners of evil across the nation, both within and outside the school environments. For instance, examination malpractice, cultism, banditry, fraud, lying, impunity, cheating, abuse of office - name it are, sadly, household names among the citizens. Perhaps the most painful and baffling aspect of it all is that those who perpetrate these despicable activities are invariably those who are undergoing or have undergone the process of education. Obviously, this is indicting to Nigerian education. Some decades back, Okolo [27] was able to underscore this point, lamenting that education in this country has not really promoted right values, even among those supposed to be educated.

\section{CONCLUSION}

Having gone thus far in the philosophical appraisal of the Nigerian education and inculcation of values, some conclusive statements can be made. It is obvious, from the issues raised and discussed, that the values outlined in the National Policy on Education are really noble and can contribute significantly to the betterment of the nation, if appropriately inculcated and practised. However, the Nigerian education has not been effective in its responsibility of inculcating values, due to some existing anomalies. One of such anomalies is the absence of value clarification. Consequent on this, Nigeria, as a nation, can hardly boast of having a value system capable of sustaining its ethical or ideological integrity. Also, teachers are ill prepared and equipped to handle the task of the inculcation of values due to their low level awareness of the value component of the National Policy on Education.

Furthermore, there is little or no influence of our cultural and social context on the determination of the values, thereby foreclosing most of our traditional and indigenous values. Again, there is an apparent over dependence on formal education, to the neglect of the informal and non-formal. Moreover, our leaders appear to have grossly fallen short of providing exemplary leadership, being models and appreciating the worth and dignity of the citizens as human persons. Instead, 
Greg Ekeh; J Adv Educ Philos, Nov 2019; 3(11): 414-419

they display their wrong doings with impunity, submerged, as they are, in their unabashed selfishness, to the detriment of the common good of all. The net result is the ugly situation in which the nation has found itself: A situation where our core cultural and social values, even the values of human life, are bastardized and on the verge of total erosion down the drain of frivolities, vainglories and deceptive maneuverings.

\section{RECOMMENDATIONS}

In the light of the above conclusion, the following recommendations are put forward:

- Values to be inculcated through education have to be expanded to include our core cultural and social values, especially the value of human life.

- Our leaders are encouraged to take the lead in the acquisition and practice of values so that they can be models to the younger generations.

- Efforts are to be made at value clarification. This will help individuals to get well informed and convinced about their value priorities, career decisions and patterns of behaviour.

- Working conditions and remunerations of teachers should be improved in order to motivate them to be more committed to their teaching and socialization of the learners.

- The policy statement on the inculcation of values should be modified, with strong emphasis on practice and the roles of other forms of education.

- In-depth knowledge of values and awareness of the policy document on education should be given adequate attention in the training and retraining of teachers of all cadres.

\section{REFERENCES}

1. Onuoha, G. B. I. (ed). (1986). Curriculum process. Ibadan: Heinemann Educational Books Nigeria Limited.

2. Dillon, A. (2004). Education in Plato's Republic. Retrieved September 28, 2019, from www.scu. edu/character/resources/education-in-platosrepublic.

3. Ekeh, G. (2009). At home with philosophy of education. Nsukka: Mike Social Press.

4. Fafunwa, A. B. (2004). History of education in Nigeria. Ibadan: NPS Educational Publishers.

5. Otite, O., \& Ogionwo, W. (2006). An introduction to sociological studies. Ibadan: Heinemann Educational Books Nigeria Plc.

6. Aggarwal, J. C. (2008). Theory and principles of education: Philosophical and sociological bases of education. New Delhi: Vikas Publishing House PVT Ltd.

7. Federal Republic of Nigeria. (2014). National policy on education. Abuja: NERDC Press.

8. Okoro, O. (2009). Branches of philosophy in education. Enugu: Ballin Publishers Nig. Ltd.

9. Nwabuisi, E. M. (2000). Values and education. Onitsha: Spiritan Publications.
10. Inlow, G. M. (1972). Values in transition: $A$ handbook. New York: John Willey \& Sons Inc.

11. Audi, R. (Ed.). (2011). The Cambridge dictionary of philosophy. United Kingdom: Cambridge University Press.

12. Osaat, S. D. (2011). Education in Africa. Port Harcourt: University of Port Harcourt Press.

13. Ifeagwazi, C. M., \& Uzondu, C. N., in Ebigbo, P. O., Ezenwa, M. O., Agoha, B. C., \& Eze, J. E. (eds.). (2010). Value system and the health of anation. Enugu: Immaculate Publications Ltd.

14. Collins. (2019). Collins English Dictionary. Retrieved September 28, 2019, from https://www. Collinsdictionary.com/dictionary/English/valuesystem.

15. Kulich, S. J., \& Chi, R. (2014). "Values Clarificatio". In: Michalos, A. C.(ed). Encyclopedia Quality of Life and Well-Being Research. Springer, Dordrecht.

16. Aggarwal, J. C. (2007). Teacher and education in a developing society. New Delhi: Vikas Publishing House PVT Ltd.

17. Osaat, S. D., \& Omordu, C. (2011). Evaluation of Value System and Its Effects on Nigeria Education: A Philosophical Approach. African Research Review, 5(5), 303-314.

18. Fan, A. F., Usman, V. I. M., \& Bawa, Y. J. (2015). "Towards Effective Teaching of Values in Nigerian Schools". In Merit Research Journal of Education and Review, 3(10): 292-298.

19. Uduigwomen, A. F. (2006). Introducing ethics: Trends, problems and perspectives. Calabar: Jochrisam Publishers.

20. Jabaar, S. O., \& Bichi, A. A.(2009). Teachers' Awareness of the Value Component of the National Policy on Education in Nigeria.

21. Ohwovorione, P. A. (2013). Moral education in Nigerian secondary schools: A realistic approach. Standard Journal of Education and Essay, 1(2), 35-39.

22. Frankena, W. K. (1979). "Toward a Philosophy of Moral Education" In Chazan, B. I., \& Soltis, J. F. Moral education. New York: Teachers College Press.

23. Haralambos, M. (2001). Sociology: Themes and perspectives. New Delhi: Oxford University Press.

24. Bodurin, P. O., (2009). Unpublished Post Graduate Seminar Paper. Lagos: Faculty of Education, Lagos State University.

25. Solarin, T., in Enoh, A. O. (1996). Main currents in Nigerian education. Jos: Mainland Publishers

26. Eluu, P. E. (2016). "The Role of Religion in Value Education in Nigeria" in British Journal of Education, 4(9), 64-69 (special issue). Available at www.eajournals.org.

27. Okolo, C. B. (1993). Education and Nigerian values: A companion for students. Enugu: SECTA Nig. Ltd. 